\title{
The impact of behavioural elements of job design on employee engagement of public sector administrative service officers in Sri Lanka
}

\author{
Dissanayake D.M.P.S.K ${ }^{1}$, Jayatilake L.V.K. ${ }^{2}$ \\ Wayamba University of Sri Lanka ${ }^{1}$, University of Kelaniya, Sri Lanka ${ }^{2}$ \\ lakminij@kln.ac.lk
}

\begin{abstract}
Public Sector should be focused on improving the productivity by empowering employees and this will be part of an overall growth strategy of the countrie's economy. Therefore, the service quality of public sector of the country is significantly important.The purpose of this study is to determine the impact of behavioural elements of Job Design on the level of employee engagement of Sri Lanka Administrative Service Officers. This quantitative study, 141 SLAS officers among 2384 SLAS officers are examined to identify the impact of each of the behavioural element tested in Hackman and Oldham's Job characteristics model on the level of Employee engagement. In addition the level of employee engagement of SLAS officers and the level of each of the five behavioural element embedded in the job of SLAS officers are measured in the study.

The results of the study indicates that $65 \%$ of the variance in Employee Engagement is explained by five behavioural elements of Job Design. It is also found that Autonomy, Task Significance and Skill Variety elemants of Job Design are positively correlated with the level of employee engagement of SLAS officers and Task Identity and Task Feedback elements of Job Design are not significantly correlated with employee engagement. The study also proved that SLAS officers are moderately engaged in their job, having moderaley positve mean values for vigour, dedication and absorption elements. The level of Autonomy and Skill Variety elements embedded in the job of SLAS officers is at a moderate level and the level of Task Significance and Task Identity elements embedded in the job of SLAS officers is at a high level. The feedback provided by the job to its holder is at a low when considering the job of the sample. A more accurate method should be developed to provide a feedback to the job holder regarding the performance.
\end{abstract}

Keywords: Administrative Service, Behavioural Elements, Job Design, Engagement

Copyright: (C) 2019 Dissanayake D.M.P.S.K, Jayatilake L.V.K. This is an open access article distributed under the Creative Commons Attribution License, which permits unrestricted use, distribution, and reproduction in any medium, provided the original work is properly cited.

Correspondence: lakminij@kln.ac.lk

DOI: http://doi.org/10.4038/kjm.v8i1.7593

Kelaniya Journal of Management | 2019 | Vol. 08 | Issue 01 | Page 86 


\section{Introduction}

Public Sector employees in Sri Lanka can be identified as a major determinant factor of the country's development and future affairs. It is shown that as a percentage of population of the country, Sri Lankan public service is one of the largest in the world (National Human Resources and Employment Policy, 2012).

According to the figures of Department of Census and Statistics of Sri Lanka, the public sector employment consists of $15.1 \%$ of total employed labour force of the country and it is 1,182,914 persons in total (Department of Census and Statistics, 2016). This amount indicates that the public sector employment has a significant impact on the country's future. It is believed that the public service is already too large and unwieldy, many institutions are overstaffed and also it is one of the largest public sectors in the world (National Human Resources and Employment Policy, 2012). Further, this total of public sector employees are employed in many government organizations which directly provide services to the general public. It is important to be noted that, public sector should be focused on improving the productivity by empowering employees and this will be a part of an overall growth strategy of the country's economy (Nafeel, 2014).

Therefore, the service quality of public sector of the country is significantly important. However according to a research done by the Transparency International Sri Lanka in 2014, it has been revealed that the service quality of most of the Sri Lankan Public Sector Organization is in low level. And also it mentions that the overall quality of the
Sri Lankan public sector has deteriorated rapidly in last five decades. (Transparency International Sri Lanka, 2014)Apart from that, there can find many public criticisms on the quality of services provided by many government organizations.Public criticisms also can be identified on low levels of employee engagement in government sector employees.

Employee engagement is an emerging concept which is adopted by many organizations. It is interwoven significantly with important business outcomes and touches almost all parts of human resource management. The concept is built on the foundation of earlier concepts like job satisfaction, employee commitment and Organizational citizenship behaviour (Markos \& Sridevi, 2010). Employee engagement which can be identified as a major determinant factor of service quality and organizational performance can be defined as "A positive, fulfilling, work related state of mind that is characterized by vigour, dedication and absorption (Bakker \& Schaufeli, 2008).

In most of the large $\&$ bureaucratic public sector organizations (Wright, 2001), engagement challenges can be identified (Southyard, 2010). Inappropriate structure or policies, disparities in compensation etc. and many other factors have caused to decrease the engagement level of public sector employees in worldwide (Southyard, 2010).

Apart from that, researchers have identified some driving factors that cause to increase the level of Employee Engagement. Meaning at work (Penna, 2007), top management of the organization, relationships between employees, personnal attributes, organizational contexts (Markos \& 
Sridevi, 2010), employee welfare, empowerment, employee growth and interpersonal relationships (Bedarkar \& Pandita, 2013) etc. have been noted as some factors that affect the level of employee engagement.

Further, according to some researchers Employee Engagement has an impact from the Job Design as well (Shantz, Alfes, \& Truss, 2013). Researchers such as Bakker and Demerouti (2008) and Hackman \& Oldham (1976) also have pointed out the impact of Job Design on the Level of Employee Engagement through illustrating JD-R Model (Bakker \& Demerouti, 2008) and Job Characteristics Model (Hackman \& Oldham, 1976).

Job design can be defined as the function of arranging tasks, duties and responsibilities into an organizational unit of work for the purpose of accomplishing a certain objective. In its expanded definition, the job design is the way to organize the contents, methods and relationship of jobs in order to achieve organizational goals and objectives as well as satisfaction of job holders (Opatha, 2009).

In designing a job, two main categories of elements are promptly considered i.e. Efficiency Elements and Behavioural Elements (Opatha, 2009). Efficiency elements consists of Division of Labour, Standardization and Specialization where Behavioural Elements of Job Design Consists five factors described in Hackman and Oldham's (1976) Job Characteristics Model (Opatha, 2009). According to the model Skill Variety, Task Identity, Task Significance, Autonomy and Feedback are identified as behavioural elements of Job Design (Hackman \& Oldham, 1976).
In brief, Skill Variety is the extent to which the job requires different skills, task significance is the extent to which the job has an impact on other people's work, autonomy is the degree of independence and freedom the job holder has, task identity is the extent to which the job involves doing some complete piece of work and Feedback is the extent to which clear information of results in respect of individual efficiency and effectiveness is provided (Opatha, 2009).

Job Design is also attached with many advantages as well. Enhancing productivity, reducing the level of absentiesm, supporting self mobility and increasing efficiency are some important value additons of appropraite Job Design (Belias \& Sklikas, 2013).Accordingly it can be identified that frequent Job Designing has a significant important in many aspects including the engagement level of employees.

However it is noted that, the designing of jobs of public sector employees is not done recently. It is reported that frequent job designing has not become the practice in Sri Lankan public sector context. Most of the jobs are designed years ago.

\section{Research Problem}

As discussed above, there is a significant public criticism on low level of service quality of most of the government organizations and some studies also have proved that the level of service quality of most of the public sector organizations has deteriorated in the last few decades (Transparency International Sri Lanka, 2014). This has affected to the general public of the country, in various aspects. 
The service quality of employees in any organisation basically depends on various factors. As argued by the researchers, service quality improvements of service organizations should be focused on the selection, training, and compensation of employees (Tsaur \& Lin, 2004). However as described by Bakker and Leiter (2010) in their book "Work Engagement", employee engagement affects to the quality of services provided by a person to the public(Bakker \& Leiter, 2010).

Some other researches focused on foreign context have identified the impact of Job Design on the Level of Employee Engagement. For instance Bakker and Demerouti (2008) and Hackman \& Oldham (1976) also have pointed out the impact of Job Design on the Level of Employee Engagement through illustrating JD-R Model (Bakker \& Demerouti, 2008) and Job Characteristics Model (Hackman \& Oldham, 1976). In specifically Bakker and Demerouti (2008), D'Souza \&Mulla (2011) etc. have tested the impact of behavioural elements of job design on employee engagement levelin different contexts (D'Souza \& Mulla, 2011) (Bakker \& Demerouti, 2008).

However, there is no published literature found in Sri Lankan context to ascertain the impact of behavioural elements of Job Design of the public sector employment to the level of Employee Engagement of them. Accordingly, it is important to conduct a study to identify the relationship between the behavioural elements of Job Design and Employee Engagement Level of government sector employees in Sri Lanka. Sri Lanka Administrative Service Officers demonstrate a significant impact on other public sector employees, it is essential identify the impact of behavioural elements of Job Design on Employee Engagement Level of Sri Lanka Administrative Service Officers of the country.

Accordingly this study aims to determine, (what are) the impact of behavioural elements of job design on employee engagement of public sector Administrative Service Officers of Sri Lanka.

\section{Research Questions}

1. What is the level of Behavioral elements embedded (included) in the job of Administrative Service officers of Sri Lanka?

2. What is the level of employee engagement of public sector Administrative service officers of Sri Lanka?

3. Whether the job design significantly affects the employee engagement level in relation to the public sector Administrative Service Officers of Sri Lanka?

\section{Research Objectives}

\section{Main Objective}

The main objective of the study is to identify the impact of behavioural elements of job design on employee engagement of public sector Administrative Service Officers of Sri Lanka.

\section{Specific Objectives}

- To ascertain the level of selected behavioural elements in relation to the job design of public sector Administrative Service Officers of Sri Lanka i.e. task feedback, task significance and autonomy

- To ascertain the level of employee engagement of public sector 
Administrative Service Officers of Sri Lanka

- To identifying the impact of behavioural elements of job design on employee engagement.

\section{Significance of the study}

Public sector of Sri Lanka represents a significant percentage of total labour force of the country. According to the statistics, it is nearly $15.1 \%$ of the total employed labour force of the country. Even though it consists a larger employee population, there are many public criticisms on the low quality service of the public sector organizations. This identified deterioration of the service quality has caused an inconvenience for the general public.

This study is to suggest the necessary attention to increase the service quality of the public sector employees through proper job design. Further it will provide suggestions on increasing performance through increasing the level of engagement of public sector employees.

\section{Population and Sample}

The total number Sri Lanka Administrative Service officers would be the population of this study. The sample will be selected based on Random Sampling method. 141 SLAS officers among 2384 SLAS officers are examined.

\section{Data Collection and Analysis}

Data Collection of the study will be done through a questionnaire based survey. Accordingly a previously tested standard questionnaire items used to collect data.
Descriptive statistics, Pearson's Correlation Analysis and Multiple Regression Analysis used in analysing data.

\section{Limitations of the Study}

This study is conducted based on the Sri Lanka Administrative Service Officers and the selected population consists only 2384 employee out of 1,182,914 of total public sector employees of the country. Accordingly, it is impossible generalize the findings on the whole public sector employment of Sri Lanka.

Further, the study is conducted on selected 141 sample of Sri Lanka Administrative Service Officers and that consists only $6 \%$ out of the total population and due to that findings may vary if the study was conducted with a different sample.

Sri Lanka Administrative Service Officers are dispersed in different types of government organizations such as departments, ministries, urban councils, authorities, divisional secretariats etc. Tasks and duties of Administrative Service Officers are widely unequable and different. Accordingly generalizing research findings may not provide accurate results.

As the sample is dispersed in a wide variety of organizations it is difficult to contact and collect data to cover all the types of organizations. It also not convenient to collect data covering all the areas of the country. $80 \%$ of the sample represent Western Province and Central Province and the rest represents North-Central and Sothern Provinces. Significant deviations may occur, if the study was conducted covering all types of organizations and all parts of the country. 
In some cases, employees' self-concept does not allow them to reveal the actual data. Some employees may be reluctant to reveal about the low level of engagement or inadequate job design due to some social factors.

\section{Job Design and Employee Engagement Level}

Many previous researches have been conducted to identify the relationship between the Job Design and employee engaement level.Quoting Hackman and Oldham (1976), hase mentioned that the presence of five key characteristics withinjobs facilitates the development of internal motivation for effective performance and these elements of the job are expected to increase positive attitudinal andbehavioural outcomes, and decrease negative ones(Shantz, Alfes, \& Truss, 2013).

Hackman \& Oldham (1976) have mentioned that Job Characteristics or behavioural elements of job design can be used to increase the performance level and the engagement of an employee (Hackman \& Oldham, 1976). Accordingly some other researchers have highlighted each of the characteristic of Job Design as driving factors of Employee Engagement (Hackman \& Oldham, 1976).

In detailed analysis of Job Characteristics model it has been pointed out that, each of this five elements or characteristics of job design are stongly related with job satisfaction, work motivation, growth satisfaction and performance (Fried \& Ferris, 1987). However, Fried and Ferris (1987) have not mentioned or identified any relationship between Job Design and Employee Engagement in his analysis of Job Characteristics Model and many researchers have omitted the important relationship between Job Design and Employee Enagement(Shantz, Alfes, \& Truss, 2013).

However some other literature emphasize this relationship between Employee Engagement and Job Design. Kahn (1990) has identified that work contexts make conditons in which employees can personally engage with their work and when people were doing work that was challenging and varied, theywere more likely to be engaged(Kahn, 1990).

Emphasizing the role of Job Design in generation Employee Engagement, the Job-Demand-Resources (JDR) model of Bakker and Demerouti (2008) has also stated that physical, social or organizational aspects of the job can be a source of engagement for people.Specifically, the JDR model states that physical, social or organizational aspects of the job canbe a source of engagement for people. This is because job resources reduce the uselesseffects of excessive work demands, increase the achievement of goals, and stimulatepersonal growth and learning (Bakker \& Demerouti, 2008).

As described by Saks (2006), it has been identified that Empolyee Enagement has a positive relationship with the five job characteristics of Hackman \& Oldham (1976). In his model Saks (2006), Saks has identified, Job Charatoristics, Percieved Organizational Support, Percieved Supervisor Support, Rewards and Recogniton, Procedurial Justice and Distributive Justice as the Antecedents of Employee Engagement, which again can be devided as Job Engagement and Organization Engagement. He also has identified some consequences of Employee Engagement that emerege as 
a result of identified Antecedents of Employee Engagement(Saks, 2006).Further explaining Saks's (2006) findings, Shantz, Alfes, \& Truss (2013) have mentioned that in Saks's model the jobcharacteristics were combined into a single measure of job enrichment due to significant theoretical and practical implications (Shantz, Alfes, \& Truss, 2013).

Saks (2006) also has found a positive relationship between Hackman \& Oldhams'Job Characteristics and Engagement. However similar to Saks's (2006) work, Shantz,Alfes, \& Truss (2013) also have combined the jobcharacteristics into a single measure of job enrichment due to significant theoretical and practical implications.

Shantz, Alfes, \& Truss(2013), have pointed out that task variety and autonomy lead to higher level of Employee Engagement. However, in all of the above-mentioned studies, the job characteristics werecombined into a composite variable with other variables that are unrelated to jobcharacteristics (e.g. leadership, social support). It is therefore impossible to disentanglewhether characteristics of the job, or other resources, led to engagement(Shantz, Alfes, \& Truss, 2013).

Some other researchers have identified the relationships between individual job characteristics and the Level of Employee Engagement level. For instance, Xanthopoulou, Bakker,
Demerouti, \& Schaufeli(2009) have identified that auotnomy is positively associated with Engagement Level (Xanthopoulou, Bakker, Demerouti, \& Schaufeli, 2009). Bakker \& Bal (2010) also have showed the positive impact of Autonomy on Employee Engagement.

\section{Research Gap}

Most of the previous studies on relationship between behavioural elements of job design and employee engagement were conducted based on foreign context. Accordingly, very less number of researches were focused on to identify the impact of behavioural elements of Job Design on Employee Engagement level of Sri Lankan public sector.

\section{Research Model of the Study}

Research model of the study was developed to test the impact of behavioural elements of Job Design on Employee Engagement of public administrative service officers.

Five behavioural elements of design (i.e. Autonomy, Task Feedback, Task Significance, Task Identity, Skill Variety) discussed in the Job Characteristics Model of Hackman \& Oldham (1976) were considered as independent variables and the Employee Engagement was considered as the dependent variable of the study.

Accordingly, following Research Model (Conceptual Framework) was developed to be tested in this study. 
Dissanayake D.M.P.S.K, Jayatilake L.V.K., KJM, 2019, 08 (01)

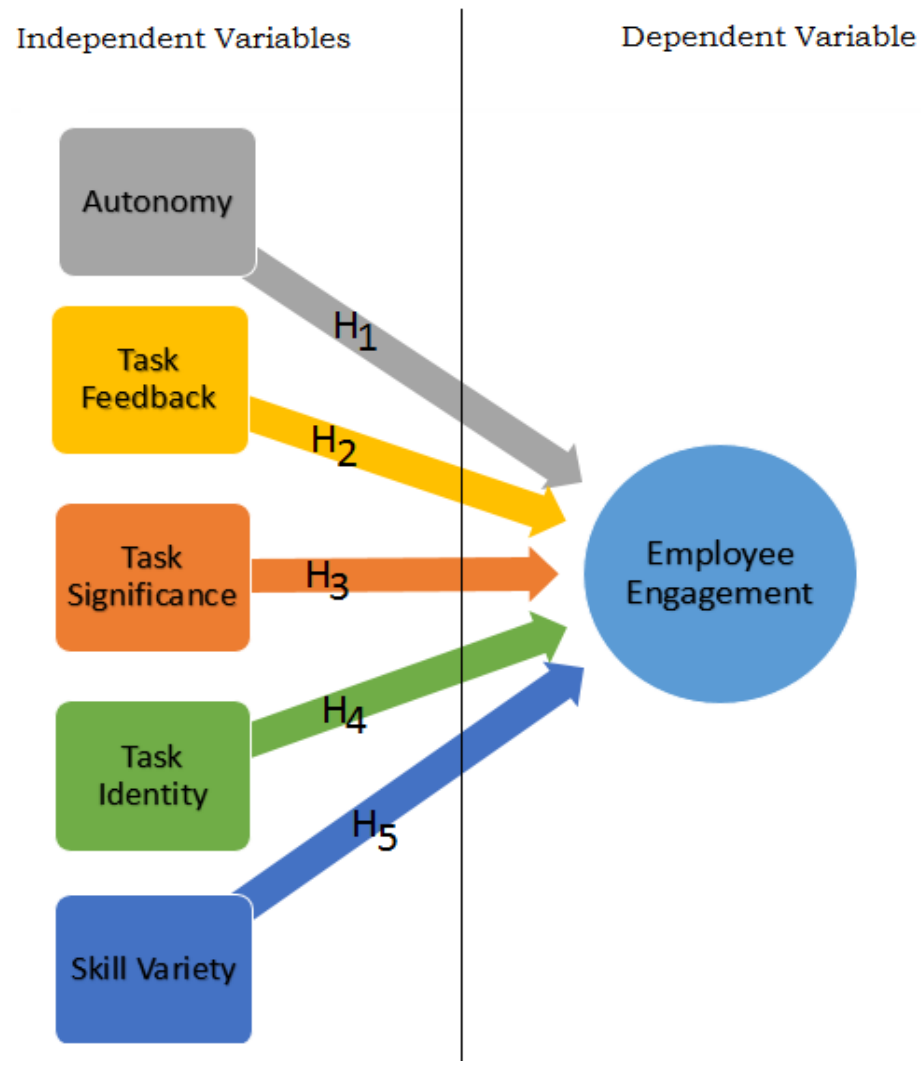

Figure 01 Conceptual Framework

\section{Factors to the Model}

The model consists five independent variables and one dependent variable which can be defined as follows.

\section{Dependent Variable - Employee Engagement}

- The engagement refers to behaviour wherein an individual is able to give physically, cognitively and emotionally while doing the job and it causes to create a positive sense of 'meaning of work' (Kahn, 1990).

- Employee engagement as defined by Bakker \&Schaufeli (2008) is positive, fulfilling, work related state of mind that is characterized by vigour dedication and absorption (Bakker \& Schaufeli, 2008). 


\section{Independent Variables - Behaviouaral Elements of Job Design}

- Autonomy - Degree to which the job provides substantial freedom, independence, and discretion to the individual in scheduling the work and in determining the procedures to be used in carrying it out (Hackman \& Oldham, 1976).

- Feedback - Degree to which carrying out the work activities required by the job results in the individual obtaining direct and clear information about the effectiveness of his or her performance (Hackman \& Oldham, 1976).

- Task Significance - Degree to which the job has a substantial impact on the lives or work of other people, whether in the immediate organization or in the external environment (Hackman \& Oldham, 1976).

- Task Identity - The degree to which the job requires completion of a "whole" and identifiable piece of work; that is, doing a job from beginning to end with a visible outcome (Hackman \& Oldham, 1976).

- Skill Variety - The degree to which a job requires a variety of different activitiesin carrying out the work, which involve the use of a number of different skills andtalents of the person. (Hackman \& Oldham, 1976)

\section{Hypothesis of the Study}

- $\mathrm{H}_{1}$ - There is a positive relationship between Autonomy provided by a job and Employee Engagement
As mentioned so far, Saks (2006), hase tested the each of the variable of Job Characteristics Model and identified their impact on the level of employee engagement level (Saks, 2006)(Shantz, Alfes, \& Truss, 2013). Further, according to Xanthopoulou, Bakker, Demerouti, \& Schaufeli(2009), Bakker \& Bal (2010) and Christian, Garza and Slaughter (2011), Autonomy provided by a job indicates a positive impact of Employee Engagement Level. Based on these researchers, the first Hypothesis $\mathrm{H}_{1}$ was developed to whether there is a positive relationship between Autonomy provided by a job and Employee Engagement level with relevant to Sri Lankan Administrative Officers.

\section{- $\mathbf{H}_{2}$ - There is a positive relationship between Task Feedback that can be gained by doing a job and Employee Engagement}

Developing second Hypothesis $\mathrm{H}_{2}$ was also done considering the findings of Saks (2006). As these resecher hase identified the positive impact of behavioural elements of a job (described in Job Characteristics Model) on the Level of Engagement Level, this Hypothesis was developed to whether there is a positive relationship between Task Feedback of a job and Employee Engagement level with relevant to Sri Lankan Administrative Officers.

\section{- $\mathrm{H}_{3}$ - There is a positive relationship between Task Significance of a job and Employee Engagement}

Saks (2006), hase tested the each of the variable of Job Characteristics Model and identified their impact on the level of employee engagement level (Saks, 2006)(Shantz, Alfes, \& Truss, 2013). 
Further, Christian, Garza and Slaughter (2011) has found that Task Significance has a positive relation to employee engagement (Christian, Garza, \& Slaughter, 2011). Accordigly, Hypothesis $\mathrm{H}_{3}$ was developed in order to test whether there is a positive relationship between Task Significance of a job and Employee Engagement level with relevant to Sri Lankan Administrative Officers.

- $\mathrm{H}_{4}$ - There is a positive relationship between Task Identity of a job and Employee Engagement

Developing second Hypothesis $\mathrm{H}_{4}$ was also done considering the Saks (2006). As this reseacher hase identified the positive impact of behavioural elements of a job (described in Job Characteristics Model) on the Level of Engagement Level, this Hypothesis was developed to determine whether there is a positive relationship between Task Identity of a job and Employee Engagement level with relevant to Sri Lankan Administrative Officers.

- $\mathrm{H}_{5}$ - There is a positive relationship between Skill Variety needed by a job and Employee Engagement

As tested by Christian, Garza and Slaughter (2011), it has been revealed that there is a positive relationship between Skill Variety and Employee Enagagement Level. Further, Saks's (2006) findings on positive relationship between behavioural elements of job design and employee engagement were based to develop this hypothesis. Accordingly this hypothesis will test whether there is a positive relationship between skill variety and employee engagement of Sri Lankan Administrative Service Officers.

\section{Analysis of Descriptive Statistics}

Descriptive Statistics were used to describe the distribution of the data set in statistical terms. Accordingly, measures of central tendency dispersion and skewness were calculated to identify the pattern of distribution of the sample.

\subsection{Measures of Central Tendency \& Dispersion}

Measures of Central Tendency and Dispersion for both dependent and independent variables can be depicted as follows.

Table 1 Measures of Central Tendency \& Dispersion - Employee Engagement

\begin{tabular}{|c|c|c|c|c|}
\hline $\begin{array}{c}\text { Variab } \\
\text { le }\end{array}$ & $\begin{array}{c}\text { Me } \\
\text { an }\end{array}$ & $\begin{array}{c}\text { Me } \\
\text { dian }\end{array}$ & $\begin{array}{c}\text { M } \\
\text { od } \\
\mathbf{e}\end{array}$ & $\begin{array}{l}\text { Stan } \\
\text { dard } \\
\text { Devi } \\
\text { ation }\end{array}$ \\
\hline Vigour & $\begin{array}{l}3.8 \\
282\end{array}$ & $\begin{array}{l}3.66 \\
67\end{array}$ & $\begin{array}{l}4.0 \\
0\end{array}$ & $\begin{array}{l}0.771 \\
18\end{array}$ \\
\hline $\begin{array}{l}\text { Dedica } \\
\text { tion }\end{array}$ & $\begin{array}{l}3.9 \\
599\end{array}$ & 4.00 & $\begin{array}{l}4.0 \\
0\end{array}$ & $\begin{array}{l}0.759 \\
94\end{array}$ \\
\hline $\begin{array}{l}\text { Absorp } \\
\text { tion }\end{array}$ & $\begin{array}{l}3.6 \\
739\end{array}$ & $\begin{array}{l}3.66 \\
67\end{array}$ & $\begin{array}{l}4.0 \\
0\end{array}$ & $\begin{array}{l}0.676 \\
89\end{array}$ \\
\hline $\begin{array}{l}\text { Overall } \\
\text { Emplo } \\
\text { yee } \\
\text { Engag } \\
\text { ement }\end{array}$ & $\begin{array}{l}3.8 \\
427\end{array}$ & $\begin{array}{l}3.88 \\
89\end{array}$ & $\begin{array}{l}3.6 \\
7\end{array}$ & $\begin{array}{l}0.622 \\
20\end{array}$ \\
\hline
\end{tabular}

Source: Survey Data, 2018 
Table 2 Measures of Central Tendency and Dispersion - Job Design

\begin{tabular}{|l|l|l|l|l|}
\hline $\begin{array}{l}\text { Varia } \\
\text { ble }\end{array}$ & $\begin{array}{l}\text { Me } \\
\text { an }\end{array}$ & $\begin{array}{l}\text { Med } \\
\text { ian }\end{array}$ & $\begin{array}{l}\text { Mo } \\
\text { de }\end{array}$ & $\begin{array}{l}\text { Stan } \\
\text { dard } \\
\text { Devi } \\
\text { ation }\end{array}$ \\
\hline $\begin{array}{l}\text { Auton } \\
\text { omy }\end{array}$ & $\begin{array}{l}3.6 \\
823\end{array}$ & 3.75 & 3.5 & $\begin{array}{l}0.596 \\
02\end{array}$ \\
\hline $\begin{array}{l}\text { Feedba } \\
\text { ck }\end{array}$ & $\begin{array}{l}2.9 \\
552\end{array}$ & 3.0 & 2.6 & $\begin{array}{l}0.799 \\
74\end{array}$ \\
\hline $\begin{array}{l}\text { Task } \\
\text { Signifi } \\
\text { cance }\end{array}$ & $\begin{array}{l}4.2 \\
428\end{array}$ & $\begin{array}{l}4.25 \\
00\end{array}$ & 4 & $\begin{array}{l}0.785 \\
91\end{array}$ \\
\hline $\begin{array}{l}\text { Task } \\
\text { Identit } \\
\text { y }\end{array}$ & $\begin{array}{l}4.6 \\
099\end{array}$ & $\begin{array}{l}4.66 \\
67\end{array}$ & $\begin{array}{l}4.6 \\
7\end{array}$ & $\begin{array}{l}0.324 \\
61\end{array}$ \\
\hline $\begin{array}{l}\text { Skill } \\
\text { Variet } \\
\text { y }\end{array}$ & $\begin{array}{l}3.8 \\
019\end{array}$ & $\begin{array}{l}3.66 \\
67\end{array}$ & $\begin{array}{l}7.6 \\
7\end{array}$ & $\begin{array}{l}0.641 \\
42\end{array}$ \\
\hline $\begin{array}{l}\text { Job } \\
\text { Design }\end{array}$ & $\begin{array}{l}\mathbf{3 . 8} \\
\mathbf{4 5 6}\end{array}$ & $\begin{array}{l}\mathbf{3 . 8 7} \\
\mathbf{5 0}\end{array}$ & $\begin{array}{l}\mathbf{3 . 8} \\
\mathbf{0}\end{array}$ & $\begin{array}{l}\mathbf{0 . 3 8 1} \\
\mathbf{2 8}\end{array}$ \\
\hline
\end{tabular}

Source: Survey Data, 2018

\section{Mean Value to measure the Level of Employee Engagement}

According to Wicramasinghe (2004), the mean value of a Lickert scale can be used to identify the overall opinion of the sample on a particular variable and also it can be used to ascertain level of that variable (High or Low). For instance, the mean value of employee engagement can be used to identify whether the Engagement Level of selected sample of employees is high, low or moderate (Wickramasinghe, 2004). Accordingly, in a Lickert Scale that comprises with numbers ranging from 1 to 5 , the middle value is 3 and 3 indicates the average/ indifferent opinion. The value over three indicates a positive opinion and value below three indicates a negative opinion.

The Mean Value of the overall engagement is 3.84 (on a scale of 5) and that value implies that the engagement level of the most of the officers of the sample lies between indifference and agree level in the Lickert scale (where 3 $=$ indifference $\& 4$ =agree). The mean value higher than the middle value of the Lickert Scale (i.e. 3) indicates a positive opinion. And since the mean value is lower than the agree level (i.e. 4) we can identify that the officers of the sample are moderately engaged in their jobs.

The Mean Value of the vigour component of employee engagement is 3.82 (on a scale of 5) and that value implies that the vigour level of the most of the officers of the sample lies between indifference and agree level in the Lickert scale. Based on the criteria of Wickramasinghe (2004) we can identify that vigour level of the officers of the sample is moderately positive.

The Mean Value of the Dedication component of employee engagement is 3.96 (on a scale of 5) and that value implies that the Dedication level of the most of the officers of the sample lies between indifference and agree level in the Lickert scale. According to the above criteria, the sample selected is moderately dedicated to their job.

The Mean Value of the Absorption component of employee engagement is 3.67 (on a scale of 5) and that value implies that the Absorption level of the most of the officers of the sample lies between indifference and agree level in the Lickert scale. According to the above criteria the sample selected is moderately absorbed to their job. 
Mean Value to measure the Level of Behavioural Elements of Job Design

In the case of five independent variables, the mean value of each of the variable can be considered as a measure of level (high or low) the each behavioural element is embedded in the job of the SLAS officers.

As per the Table 02 the mean values of Autonomy, is 3.68 (on a scale of 05). According to criteria of Wickramasinghe (2004) the mean value of Autonomy implies that the level of autonomy provided by the job of the sample officers lies between indifference and agree level in the Lickert Scale. Accordingly the job of the SLAS officers is adding a moderate level of autonomy.

The Mean Value of the next considered behavioural element, feedback (2.95) implies that the level of feedback provided by the job of the sample lies below the indifference level of the Lickert Scale. Accordingly it implies that the job of an SLAS officer does not provide the adequate level of direct and clear information about the effectiveness of his or her performance.

The Mean Value of the Task Significance element of Job design is 4.24 (on a scale of 5) and that value implies that it lies between agree and strongly agree level in the Lickert scale. Accordingly, the task significance of the job of SLAS officers is at a high level.

Having mean value of 4.61 (on a scale of 05) of task identity indicates that the degree to which the job requires completion of a "whole" and identifiable piece of work is at a high level.
The mean value of skill variety ( 3.80 on a scale of 5) also implies the moderate level of skill variety required by the job of the SLAS officers.

Finally, the mean value (3.85) for overall level of behavioural elements of job design implies that according to the view of the sample, a moderately high level of behavioural elements are embedded in the job of the SLAS officers.

\section{Mean Value to Compare the Components of Employee Engagement}

According to Devi \&Narayanamma (2016) the mean value could be used to compare components or sub variables of a particular variable.

If considered, Table 01 that the mean score of dedication component of employee engagement as perceived by the respondents is 3.9599 on a scale of 5 which is slightly good when compared to absorption and vigour. This implies that dedication of SLAS officers regarding one's work is high when compared to other components i.e. absorption and vigour.

\section{Mean Value to Compare Behavioural Elements of Job Design}

As given in the Table 02, the mean value of Task Identity component as perceived by respondents is 4.61 (on a scale of 5) which is reasonably good when compared to other four behavioural elements. The value indicates that the task identity element is more embedded in the job of the SLAS officers when compared to other four elements. The lower mean value of feedback element (2.99 on a scale of 05) indicates that, feedback element is les embedded in the job of the SLAS officers. 


\section{Normality}

The employee engagement components and Job design elements show close figures for central tendency measures (i.e. mean, median and mode) of each variable, and it implies that the distribution of data lies at the centres of the distributions and indicates fairly normal distributions. (In Normal Distribution, Mean $=$ Median $=$ Mode $)$.

\section{Skewness and Kurtotis Measures}

Skewness and Kurtotis Measures were used to identify the shape of the distribution or the direction of variance of both dependent and independent variables.

Table 3 Skewness and Kurtotis

\begin{tabular}{|l|l|l|}
\hline & $\begin{array}{l}\text { Skewnes } \\
\mathbf{S}\end{array}$ & $\begin{array}{l}\text { Kurtoti } \\
\mathbf{S}\end{array}$ \\
\hline Job Design & $\mathbf{- 1 . 1 6 3}$ & $\mathbf{0 . 5 6 2}$ \\
\hline Autonomy & -0.085 & -0.557 \\
\hline Feedback & -0.081 & 4.452 \\
\hline $\begin{array}{l}\text { Task } \\
\text { Significance }\end{array}$ & -1.781 & -0.635 \\
\hline $\begin{array}{l}\text { Task } \\
\text { Identity }\end{array}$ & -0.389 & 4.155 \\
\hline Skill Variety & -1.036 & 3.810 \\
\hline $\begin{array}{l}\text { Employee } \\
\text { Engagemen } \\
\boldsymbol{t}\end{array}$ & $\mathbf{- 0 . 9 9 6}$ & $\mathbf{3 . 7 0 9}$ \\
\hline Vigour & -0.447 & 1.331 \\
\hline Dedication & -1.061 & 2.297 \\
\hline Absorption & -0.179 & 0.261 \\
\hline
\end{tabular}

Source: Survey Data, 2018

\section{Skewness}

Skewness is basically used to identify the pattern of distribution. According to the criteria to measure the skewness of a distribution mentioned by Hildebrand (1986), accepted range of skewness for symmetric distribution is considered as $-1<\mathrm{sk}<+1$. Accordingly if the skewness value is less than -1 the distribution is considered as negatively skewed and if the value is more than +1 then it is considered as positively skewed.

The skewness of the overall employee engagement (Dependent Variable) is 0.996 and it implies a symmetric/ normal distribution of the data. [Accepted range of Skewness for symmetric distribution is considered as $-1<\mathrm{sk}<1 \quad$ (Hildebrand, 1986)] According to the criteria both Vigour and absorption imply symmetric/ normal distribution. However the dedication factor is negatively skewed and exhibits outliers at the low end of the distribution.

According to figures of the above Table 03, the skewness values of the behavioural elements of job design (independent variables) are Autonomy $=-0.085$, Feedback $=-0.081$, Task Significance $=-1.781$, Task Identity $=$ 0.389 and Skill Variety $=-1.036$. As per these figures we can identify both Skill Variety and Task Significance elements are negatively skewed in the distribution whereas Autonomy, Task Feedback and Task Identity shows a symmetric/ normal distribution. The overall distribution of the behavioural elements of job design is also negatively skewed with a skewness value of 1.163. 


\section{Normality Test}

Even though the skewness and histograms provides an idea about the distribution of the data set, the values of normality tests provides a more accurate information about the distribution of the sample. There are various methods that researchers used to identify the distribution pattern of variables. In this study KolmogorovSmirnov (K-S) test and Q-Q Plots are used to identify the distribution pattern of the dependent variable (Employee Engagement).

\section{Kolmogorov-Smirnov (K-S) test}

Kolmogorov-Smirnov (K-S) test was conducted to identify the level of probability distribution of the Dependent Variable. The accepted criteria for test of Normality is, if the ' $p$ ' value (or significance value) is less than 0.05 , it shows a significance difference from normality (not normal distribution).

According to the test results, the 'p'value of Employee Engagement is equal to 0.05 and it indicates a normal distribution in the sample.

\section{$Q-Q$ Plots}

Q-Q Plot was drawn to identify the normality of the Employee Engagement Variable (Dependent Variable).

When identifying the distribution type of the Variable using Q-Q Plots, we have to consider the placement of plots in the graph. If the plots are placed on the diagonal of the chart, such a distribution is considered as normally distributed.

As most of the plots of the Q-Q Plot is placed on diagonal line, it is assumed that employee engagement level is normally distributed.

\section{Testing of Hypotheses}

The hypotheses testing was conducted by using the results of Correlation Analysis and Multiple Regression Analysis which are used to determine the relationship between each of the five independent variables and the dependent variable.

The results of Pearson's Correlation analysis used to test the hypothesis are presented in the Table 04. The desired level of significance is 0.01 . Two tailed test was used to conduct the Correlation Analysis.

Table 4 The Relationship between Behavioral Elements of Job Design and Employee Engagement (See Appendix G)

\begin{tabular}{|l|l|}
\hline $\begin{array}{l}\text { Behavioral } \\
\text { Elements } \\
\text { Job Design }\end{array}$ & $\begin{array}{l}\text { Oorrelation } \\
\text { between } \\
\text { Employee } \\
\text { Engagement }\end{array}$ \\
\hline Autonomy & $0.778^{* *}$ \\
\hline Task Feedback & 0.082 \\
\hline $\begin{array}{l}\text { Task } \\
\text { Significance }\end{array}$ & $0.456^{* *}$ \\
\hline Task Identity & -0.050 \\
\hline Skill Variety & $0.595^{* *}$ \\
\hline
\end{tabular}

Source: Survey Data, 2018

** Correlation is significant at the 0.01 level (2tailed)

According to the above Table 04, Pearson's Correlation Coefficient suggests that there is a positive relationship between all independent variables except Task Identity. So that, 
there is a statistical evidence to confirm there is a positive relationship between Autonomy, Task Feedback, Task Significance \& Skill Variety and the Dependent Variable, Employee Engagement. Therefore Hypotheses of these four variables could be accepted, but only Autonomy, Task Significance and Skill Variety significantly correlate with Employee Engagement ( $\mathrm{p}<=0.05$ ). Rejecting the Hypotheses, Task Identity indicates a negative relationship with employee engagement, which is not significant $(\mathrm{p}>0.05)$.

$\mathrm{H}_{1}$ - There is a positive relationship between Autonomy provided by a job and Employee Engagement

Table 5 Correlation between Autonomy \& Employee Engagement

\begin{tabular}{|l|l|}
\hline & $\begin{array}{l}\text { Correlation } \\
\text { between Autonomy } \\
\text { \& Employee } \\
\text { Engagement }\end{array}$ \\
\hline $\begin{array}{l}\text { Pearson } \\
\text { Correlation }\end{array}$ & $0.778^{* *}$ \\
\hline $\begin{array}{l}\text { Sig. (2- } \\
\text { tailed) }\end{array}$ & 0.000 \\
\hline $\mathrm{N}$ & 120 \\
\hline
\end{tabular}

Source: Survey Data, 2018

** Correlation is significant at the 0.01 level (2 tailed)

For this Analysis, the Autonomy is positively correlated against is the Employee Engagement and according to the correlation analysis it is 0.778 at significant level of 0.01 (Two tailed test). Accordingly it indicates a moderately positive relationship between Autonomy and Employee Engagement and statistically significant at $99 \%$. Therefore Hypotheses one $\left(\mathrm{H}_{1}\right)$ is accepted.

H2 - There is a positive relationship between Task Feedback that can be gained by doing a job and Employee Engagement

Table 6 Correlation between Task Feedback \& Employee Engagement

\begin{tabular}{|l|lr|}
\hline & $\begin{array}{l}\text { Correlation } \\
\text { between } \\
\text { Feedback } \\
\text { Employee } \\
\text { Engagement }\end{array}$ & $\begin{array}{r}\text { Task } \\
\text { \& }\end{array}$ \\
\hline $\begin{array}{l}\text { Pearson } \\
\text { Correlation }\end{array}$ & 0.082 \\
\hline $\begin{array}{l}\text { Sig. } \\
\text { tailed })\end{array}$ & 0.370 \\
\hline $\mathrm{N}$ & 121 \\
\hline
\end{tabular}

Source: Survey Data, 2018

For this Analysis, the Task Feedback claims no relationship as the value of the Pearson Correlation lies between 0.2 and +0.2 at a not significant level ( $\mathrm{p}$ $>$ 0.05). Accordingly, a significant positive relationship between Task Feedback and Employee Engagement cannot be identified. Therefore Hypotheses two (H2) is rejected.

$\begin{array}{llr}\text { H3 - There } & \text { is } \quad \text { a } & \text { positive } \\ \text { relationship } & \text { between } & \text { Task } \\ \text { Significance of a job and } & \text { Employee } \\ \text { Engagement } & & \end{array}$


Table 7 Correlation between Task Significance and Employee Engagement

\begin{tabular}{|l|lr|}
\hline & $\begin{array}{l}\text { Correlation } \\
\text { between } \\
\text { Significance } \\
\text { Employee } \\
\text { Engagement }\end{array}$ & $\begin{array}{r}\text { Task } \\
\text { \& }\end{array}$ \\
\hline $\begin{array}{l}\text { Pearson } \\
\text { Correlation }\end{array}$ & $0.456^{* *}$ \\
\hline $\begin{array}{l}\text { Sig. (2- } \\
\text { tailed) }\end{array}$ & 0.000 \\
\hline $\mathrm{N}$ & 125 \\
\hline
\end{tabular}

Source: Survey Data, 2018

** Correlation is significant at the 0.01 level (2 tailed)

For this Analysis, the Task Significance is positively correlated against is the Employee Engagement and according to the correlation analysis it is 0.456 at significant level of 0.01 (Two tailed test). Accordingly, it indicates a weakly positive relationship between Task Significance and Employee Engagement and statistically significant at $99 \%$. Therefore Hypotheses three $\left(\mathrm{H}_{3}\right)$ is accepted.

$\mathrm{H}_{4}$ - There is a positive relationship between Task Identity of a job and Employee Engagement
Table 8 Correlation between Task Identity and Employee Engagement

\begin{tabular}{|l|lr|}
\hline & $\begin{array}{l}\text { Correlation } \\
\text { between } \\
\text { Identity } \\
\text { Employee } \\
\text { Engagement }\end{array}$ & Task \\
\hline $\begin{array}{l}\text { Pearson } \\
\text { Correlation }\end{array}$ & -0.050 \\
\hline $\begin{array}{l}\text { Sig. (2- } \\
\text { tailed) }\end{array}$ & 0.370 \\
\hline $\mathrm{N}$ & 121 \\
\hline
\end{tabular}

Source: Survey Data, 2018

For this Analysis, the Task Identity claims no relationship as the value of the Pearson Correlation lies between 0.2 and +0.2 at a not significant level ( $p$ $>$ 0.05). Accordingly, it cannot be identified a significant positive relationship between Task Identity and Employee Engagement. Therefore Hypotheses four $\left(\mathrm{H}_{4}\right)$ is rejected.

$\mathrm{H}_{5}$ - There is a positive relationship between Skill Variety needed by a job and Employee Engagement

Table 9 Correlation between Skill Variety and Employee Engagement

\begin{tabular}{|l|l|}
\hline & $\begin{array}{l}\text { Correlation between } \\
\text { Skill Variety \& } \\
\text { Employee } \\
\text { Engagement }\end{array}$ \\
\hline $\begin{array}{l}\text { Pearson } \\
\text { Correlation }\end{array}$ & $0.650^{* *}$ \\
\hline $\begin{array}{l}\text { Sig. (2- } \\
\text { tailed) }\end{array}$ & 0.000 \\
\hline $\mathrm{N}$ & 113 \\
\hline
\end{tabular}

Source: Survey Data, 2018 
** Correlation is significant at the 0.01 level (2 tailed)

For this Analysis, the Skill Variety is positively correlated against the Employee Engagement and according to the correlation analysis, it is 0.650 at significant level of 0.01 (Two tailed test). Accordingly, it indicates a moderately positive relationship between Skill Variety and Employee Engagement and statistically significant dependent variable. The results of regressing the five independent variables against the dependent variable Employee Engagement are shown in Table. at $99 \%$. Therefore Hypotheses five $\left(\mathrm{H}_{5}\right)$ is accepted.

\section{Regression Analysis}

Correlation Analysis is used to measure the relationship between each of the independent variables and the dependent variable. Regression Analysis evaluates the simultaneous effects of all the independent variables on

Table 10 Aggregate Impact of Behavioral elements of Job Design on Employee Engagement

\begin{tabular}{|c|l|l|l|l|l|}
\hline $\mathbf{R}$ & $\mathbf{R}^{2}$ & Adjusted $\mathbf{R}^{2}$ & \multicolumn{1}{|c|}{$\begin{array}{c}\text { Std. error of the } \\
\text { estimate }\end{array}$} & F & Sig. F \\
\hline 0.810 & 0.657 & 0.641 & 0.36102 & 40.959 & 0.000 \\
\hline
\end{tabular}

Source: Survey Data, 2018

In the above table the $\mathrm{R}^{2}$ (Coefficient of determination) is 0.657 indicating that the $65 \%$ of variance in Employee Engagement is explained by the five independent variables (jointly). The $\mathrm{F}$ value is 40.959 that is significant at $\mathrm{p}=$ 0.000 suggesting that five independent variables have collectively explained the $65 \%$ of the variance in Employee Engagement.

The strength of influence of each of the independent variable to the Employee Engagement (the dependent variable) is determined by the use of multiple regression coefficients (Enter Method) of the each of the independent variable. 
Dissanayake D.M.P.S.K, Jayatilake L.V.K., KJM, 2019, 08 (01)

Table 11 Influence of behavioral elements of job design on employee engagement

\begin{tabular}{|c|c|c|c|c|c|}
\hline Variable & B & Std. Error & Standardized beta & T & Significance \\
\hline (Constant) & 0.702 & 0.588 & & 1.194 & 0.235 \\
\hline Autonomy & 0.648 & 0.074 & 0.633 & 8.734 & 0.000 \\
\hline Task Feedback & -0.034 & 0.045 & -0.753 & -0.753 & 0.453 \\
\hline Task Significance & 0.073 & 0.047 & 0.100 & 1.549 & 0.124 \\
\hline Task Identity & -0.057 & 0.109 & -0.030 & -0.529 & 0.598 \\
\hline Skill Variety & 0.197 & 0.072 & 0.205 & 2.748 & 0.007 \\
\hline
\end{tabular}

Source: Survey Data, 2018

According to the figures in the above table, Autonomy indicates the most significant positive effect on Employee Engagement with a beta value of 0.633 . Then, Skill Variety shows a significant positive effect on Employee Engagement with a beta value of 0.205. The other three independent variables (i.e. Task Feedback, Task Significance and Task Identity) do not indicate any significant impact on Employee Engagement as the ' $p$ ' values of the regression of the three variables are higher than 0.05 .
A stepwise regression analysis was conducted to find out the extent of contribution of each variable to the total explanatory power of the regression model.

As shown in the Table 11, it can identified that Autonomy and Skill Variety significantly contribute to the explanatory power of the regression model. 
Dissanayake D.M.P.S.K, Jayatilake L.V.K., KJM, 2019, 08 (01)

Table 12 Stepwise Multiple Regression Analysis - Predictors of Employee Engagement

\begin{tabular}{|c|c|c|c|c|c|}
\hline Variable & B & $\begin{array}{c}\text { Std. } \\
\text { Error }\end{array}$ & $\begin{array}{c}\text { Standardized } \\
\text { beta }\end{array}$ & $\mathbf{t}$ & Significance \\
\hline (Constant) & 0.485 & 0.239 & & 2.027 & 0.045 \\
\hline Autonomy & 0.647 & 0.072 & 0.631 & 9.033 & 0.000 \\
\hline Skill Variety & 0.241 & 0.067 & 0.251 & 3584 & 0.001 \\
\hline
\end{tabular}

Source: Survey Data, 2018

Table 13 Stepwise Multiple Regression Analysis - Model Summary

\begin{tabular}{|c|c|c|}
\hline Variables & $\mathbf{R}^{\mathbf{2}}$ & Change in $\mathbf{R}^{\mathbf{2}}$ \\
\hline Autonomy & 0.605 & 0.605 \\
\hline Skill Variety & 0.647 & 0.041 \\
\hline
\end{tabular}

Source: Survey Data, 2018

The results of the multiple regression analysis indicates that Autonomy has the highest beta value contributed to the $60.5 \%$ to the variance of Employee Engagement. The Skill Variety contributes $4.1 \%$ to the variance of Employee Engagement. Other three variables, namely Task Significance, Task Feedback and Task Identity do not contribute to the total explanatory power. The figures also indicates that Autonomy and Skill Variety explains $64.7 \%$ of the variation in Employee Engagement. (See Appendix $\mathrm{H}$ for more information on statistics)

According to the prevailing literature, Saks (2006), and Hackman \& Oldham (1976), have revealed that each of the five job characteristics claim a positve relationship with employee engagement. Further, Shantz, Alfes, \& Truss (2013) have mentioned that skill variety and autonmy indicates a positive relationship with employee engagement. Xanthopoulou, Bakker, Demerouti, \& Schaufeli (2009) have also identified that auotnomy is positively associated with Engagement Level.

Eventhough previous literature explains some definite positive relationships that exist between each of the behavioural elements of job design and the level of employee engagement, the current study does not indicate such positive relationships between each of the all five behavioural elements of job design and the level of employee engagement of Sri Lanka Administrative Service Officers. In this study, Autonomy is the most related behavioural element of job design with employee engagement. Skill Variety and Task Significance are also correlated with Employee Engagement. Though the literature states otherwise, the study indicates a no relationship between Task Feedbak and Task Identity elements with the Kelaniya Journal of Management | 2019 | Vol. 08 | Issue 01 | Page 104 
level of the employee engagement. According to the regression analysis, Task Significance, Task Identity and Task Feedback do not indicate any significant impact on employee engagement. The discripancy between the results of the current study and findings of previuos litrature may have been occurred as result of unique charactoristics of the selected sample.

\section{Findings of the Study}

\section{Findings of the Hypotheses Testing}

The hypotheses testing of the study was conducted by using the results of Correlation Analysis and Multiple Regression Analysis which are used to determine the relationship between each of the five independent variables and the dependent variable. Accordingly the findings can be summarized as follows.

\section{- $\mathrm{H}_{1}$ - There is a positive relationship between Autonomy provided by a job and Employee Engagement}

Finings indicates moderately positive relationship between Autonomy element of Job Design and Employee Engagement of SLAS officers (Pearson's correlation value $=0.778$ ) . Previous researchers such as Saks (2006), hase tested the each of the variable of Job Characteristics Model and identified their impact on the level of employee engagement level \{Saks (2006), Shantz, Alfes, \& Truss (2013)\}. Further, according to Xanthopoulou, Bakker, Demerouti, \& Schaufeli (2009) and Christian, Garza and Slaughter (2011), Autonomy provided by a job indicates a positive impact of Employee Engagement Level. Accordingly, previous research findings also supports the findings of the current research.

\section{- $\mathrm{H}_{2}$ - There is a positive relationship between Task Feedback that can be gained by doing a job and Employee Engagement}

As per the findings of the current research, it indicates there is no significant relationship between Task Feedback element of Job Design and the level of Employee Engagement of SLAS Officers $(p>0.05)$. Even though, the current research findings indicates a no relationship between Task Feedback and Employee Engagement, the previous findings states otherwise and many previous researchers have identified positive relationship between two variables. Researchers such as Saks (2006) hase identified the positive impact of behavioural elements of a job (described in Job Characteristics Model) on the Level of Engagement Level. This discrepancy between current research findings and the available litrature may have been occurred as a result of unique charactoristics of the selected sample. For instance approximately $80 \%$ of the sample consisted SLAS officers who do not directly get exposed to the general public and the sample hardly exposed to feedback from their stakeholders. Accordingly their engagement level does not significantely get correlated with the level of feedback.

\section{$\mathrm{H}_{3}$ - There is a positive relationship between Task Significance of a job and Employee Engagement}

Findings of the study indicates a weakly positive relationship between Task Significance element and Employee Engagement (Correlation Analysis Value $=0.456$ ). Previous research findings also supports the current study and accordingly Saks (2006), hase tested the each of the variable of Job Characteristics Model and identified 
their impact on the level of employee engagement level (Saks, 2006)(Shantz, Alfes, \& Truss, 2013). Further, Christian, Garza and Slaughter (2011) has found that Task Significance has a positive relationship to employee engagement (Christian, Garza, \& Slaughter, 2011).

\section{- $\mathrm{H}_{4}$ - There is a positive relationship between Task Identity of a job and Employee Engagement}

As per the findings of the current research, it indicates no significant relationship between Task Identity element of Job Design and the level of Employee Engagement of SLAS Officers ( $p>0.05)$. Even though the study indicates a no relationship between two variables, previous research findings have proved a positive relationship between Task Identity and Employee Engagement. Accordingly, Saks (2006) and hasidentified the positive impact of behavioural elements of a job (described in Job Characteristics Model) on the Level of Engagement Level. This discrepancy between current research findings and the available litrature may have been occurred as a result of unique charactoristics of the selected sample. For instance the job of SLAS officers is a routine job which highly depends on the service minute of Sri Lanka administrative service(Government of Sri Lanka, 2013). Eventhough the task identity of the job of the sample is at a high level it does not affect the level of employee engagement due to the routineness and the boredness of the job.

\section{$\mathrm{H}_{5}$ - There is a positive relationship between Skill Variety needed by a job and Employee Engagement}

Findings indicate a moderately positive relationship between Skill Variety element of Job Design and Employee Engagement of SLAS officers (Pearson's correlation value $=0.650$ ) . Previous Literature also supports the current findings. As tested by Christian, Garza and Slaughter (2011)and Saks (2006) have been revealed that there is a positive relationship between Skill Variety and Employee Enagagement Level.

\section{Findings of the Multiple Regression Analysis}

As per the results of Multiple Regression Analysis, Autonomy $(60.5 \%)$ and Skill Variety $(4.1 \%)$ explains $64.7 \%$ of the variation in Employee Engagement of SLAS officers whereas the other three independent variables do not significantly explain the variation of Employee Engagement. However, prevailing literature claims that there is a positive impact on employee engagement by each of the behavioral element of job design. According to the prevailing literature, Saks (2006), and Hackman\& Oldham (1976), have revealed that each of the five job charactoristic claim a positve relationship with employee engagement. Further, Shantz, Alfes, \& Truss (2013) have mentioned that skill variety and autonomy indicates a positive relationship with employee engagement. Xanthopoulou, Bakker, Demerouti, \& Schaufeli (2009) have also identified that auotnomy is positively associated with Engagement Level. As discussed above in this chapter, This discrepancy between current research findings and the available litrature may have been occurred as a result of unique charactoristics of the selected sample. 


\section{Conclusion of the Study}

In hypothesis testing, it is found that Autonomy, Task Significance and Skill Variety elemants of Job Design are positively correlated with the level of employee engagement and confirm the prevailing theoritical arguments explained in the Literature. Among the above three independent variables, Autonomy and Skill Variety indicats moderately positive relationship with employee engagement whereas Task Significance element is weakly correlated with the dependent variable. Opposing to the prevailig literature, in the current study it is also found that Task Identity and Task Feedback elements of Job Design are not significantly correlated with employee engagement.

The study also indicates that, $65 \%$ of the variance in Employee Engagement is explained by five behavioural elements of Job Design. Multiple Regression Analysis further suggests that two variables out of five independent variables; namely Autonomy and Skill Variety are found to be explanatory factors having significant effects on Employee Engagement. The Autonomy has the strongest effect on the variance of employee engagement.

The findings of the descriptive statistics revealed that SLAS officers of the sample are moderately engaged in their job, having moderaley positve mean values for vigour, dedication and absorption elements. The level of Autonomy and Skill Variety elements embedded in the job of SLAS officers is at a moderate level and the level of Task Significance and Task Identity elements embedded in the job of SLAS officers is at a high level. The feedback provided by the job to its holder is at a low when considering the job of the sample.

\section{Future Research and Recommendations}

Although this study has provided some important insights into the relationships between behavioural elements of Job Design and the Level of Employee Engagement, it does not provide any hint on the low level of service quality of public sector organizations. Accordingly, future research should focus on identifying other factors that may affect the service quality of the public sector. The research also may focus to identify other factors such as efficiency elements of job design etc. that affect the level of employee engagement. The future research also can be expanded to identify the impact of elements of Job Design on the Level of employee engagement of different levels of employees in public sector.

Since the Employee Engagement level of SLAS officers is at moderate level the authorities should take necessary steps to increase the engagement level by increasing vigour, absorption and dedication. Factors other than behavioural elements of Job Design that may affect the level of Employee Engagement should be taken in to grant in increasing the level of employee engagement. A more accurate method should be developed to provide a feedback to the job holder regarding his performance. Use of vareid skills and having autonomy in the job should be considered by the authorites when developing jobs.

\section{Declaration of Conflicting Interests}

The authors declared no potential conflicts of interest with respect to the research, authorship and publication of this article. 


\section{References}

Bakker. (2011). An Evidence-Based Model of Work Engagement. SAGE, 265-269.

Bakker, A. B., \& Demerouti, E. (2008). Towards a model of work. Career Development International, 209-223.

Bakker, A. B., \& Leiter, M. P. (2010). Work Engagement. Hove and NewYork: Psychology Press.

Bakker, A. B., \& Leiter, M. P. (2010). Work Engagement: A Handbook of Essential Theory and Research. Hove, Newyork: Psychology Press.

Bakker, A. B., \& Schaufeli, W. B. (2008). Positive organizational behavior: Engaged employees in flourishing organizations. Journal of Organizational Behavior, 147-154.

Bakker, A. B., Demerouti, E., \& Verbeke, W. (2004). Using The Job Demands-Resources. Human Resource Management, 83-104.

Bedarkar, M., \& Pandita, D. (2013). A study on the drivers of employee engagement impacting. Social and Behavioral Sciences, 106-115.

Belias, D., \& Sklikas, D. (2013). Aspects of Job Design. International Journal of Human Resource Management and Research, 85-93.

Christian, M. S., Garza, A. S., \& Slaughter, J. E. (2011). Work Engagement: A Quantitative Review And Test Of Its Relations With Task And Contextual Performance. PERSONNEL PSYCHOLOGY, 89-136.

D’Souza, P., \& Mulla, Z. R. (2011). Can an Entrepreneurial Personality Compensate for a Boring Job? The Influence of Proactive Personality and
Job Characteristics on Employee Engagement Levels. The Journal of Entrepreneurship, 207-226.

Department of Census and Statistics. (2016). Sri Lanka Labour Force Survey - Annual Report 2015. Colombo: Department of Census and Statistics.

Devi, V. R., \& Narayanamma, P. L. (2016). Impact of Leadership Style on Employee Engagement. Public Business Review International.

Fried, Y., \& Ferris, G. R. (1987). The Validity Of The Job Characteristics Model: A Review And Meta-Analysis. PERSONNEL PSYCHOLOGY, 287322.

Government of Sri Lanka. (2013, 12 23). The Gazette of the Democratic Socialist Republic of Sri Lanka Extraordinary. Minute of the Sri Lanka Administrative Service. Sri Lanka: Department of Government Printing, Sri Lanka.

Hackman, R., \& Oldham, G. R. (1976). Motivation through the Design of Work: Test of a. Organizational Behaviour and Human Performance, 250-279.

Hildebrand, D. K. (1986). Statistical thinking for behavioral scientists. Boston: Duxbury.

Kahn, W. A. (1990). Psychological Conditions of Personal Engagement And Disengagement At Work. Academy of Management Journal, 692724.

Markos, S., \& Sridevi, M. S. (2010, December). Employee Engagement: The Key to Improving Performance. International Journal of Business and Management, 5(12), 89-96. 
Nafeel, A. C. $(2014,11)$. Productivity in the Public Sector Organizations: Empowering Workforce for the Wellbeing of the People. SLIDA News Letter, p. 1.

National Human Resources and Employment Policy. (2012, 11 15). Public Service Employment. Retrieved 07 07, 2017, from National Human Resources and Employment Policy: http://www.nhrep.gov.lk/index.php?opt ion $=$ com_content $\&$ view $=$ article $\& i d=1$ $10 \&$ Itemid $=59 \&$ lang $=\mathrm{en} \% 20 /$

Opatha, H. H. (2009). Human Resource Management. Nugegoda: University of Sri Jayewardenapura. .

Penna. (2007). MEANING AT WORK. Penna.

Saks, A. M. (2006). Antecedents and consequences of employee engagement. Journal of Managerial Psychology, 21(7), 600-619.

Shantz, A., Alfes, K., \& Truss, C. (2013). The role of employee engagement in the relationship between job. The International Journal of Human Resource Management, 26082627.

Southyard, R. N. (2010). Employee Engagement and Service Quality. Washington: Washington State University.

Transparency International Sri Lanka. (2014). Retrieved 2 4, 2017, from Public Service and the Public Service Commission of Sri Lanka: http://www.tisrilanka.org/wpcontent/uploads/2015/07/Study-onPSC-Sri-Lanka-2014.pdf

Tsaur, S. H., \& Lin, Y. C. (2004). Promoting service quality in tourist hotels: the role of HRM practices and service behavior. Tourism Management, 25, 471-481.

Wickramasinghe, E. S. (2004). Research Methods for Management Studies. Kurunegala: Asliya Printers.

Wright, B. E. (2001). Public-Sector Work Motivation:. Journal of Public Administration Research and Theory, 559-586.

Xanthopoulou, D., Bakker, A. B., Demerouti, E., \& Schaufeli, W. B. (2009). Work engagement and financial returns: A diary study on the role of job and personal resources. Journal of Occupational and Organizational Psychology, 183-200. 